\title{
Functional probiotics of lactic acid bacteria from Hu sheep milk
}

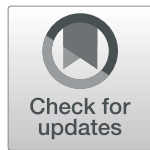

Taohong Chen ${ }^{1,2}$, Leli Wang ${ }^{1,2}$, Qinxin Li ${ }^{1,2}$, Yingjie Long ${ }^{1,2}$, Yuming Lin ${ }^{1,2}$, Jie Yin ${ }^{1,2}$, Yan Zeng ${ }^{1,2}$, Le Huang ${ }^{1,2}$, Tingyu Yao ${ }^{1,2}$, Muhammad Nazeer Abbasi ${ }^{3}$, Huansheng Yang ${ }^{1,2}$, Qiye Wang ${ }^{1,2}$, Congjia Tang ${ }^{1,2}$, Tahir Ali Khan ${ }^{1}$, Qiuyue Liu', Jia Yin ${ }^{1,2^{*}}$, Qiang Tu ${ }^{3^{*}}$ and Yulong Yin ${ }^{1,2,5}$

\begin{abstract}
Background: Probiotics are being considered as valuable microorganisms related to human health. Hu sheep is referred as one of the important sheep breeds in China. Goat milk produced by Hu sheep is characterized with high nutritional value and hypoallergenic in nature. Particularly, this milk contains plenty of milk prebiotic and probiotic bacteria. This study was aimed to scrutinize more bacterial strains from Hu sheep milk with potential probiotic activity.

Results: Based on 165 rRNA sequence analysis, pool of forty bacterial strains were identified and evaluated their antimicrobial activities against Staphylococcus aureus, enterohemorrhagic Escherichia coli (EHEC), Salmonella typhimurium, Listeria monocytogenes enterotoxigenic E. coli (ETEC) and Aeromonas caviae. Four out of these isolated strains demonstrated their efficient bacteriostatic ability and potential healthy properties. We also examined the safety aspects of these bacterial candidates including three Lactococcus lactis strains (named as HSM-1, HSM-10, and HSM-18) and one Leuconostoc lactis strain (HSM-14), and were further evaluated via in vitro tests, including antimicrobial activity, cell surface characteristics (hydrophobicity, co-aggregation, and self-aggregation), heat treatment, antibiotic susceptibility, simulated transport tolerance in the gastrointestinal tract, and acid/bile tolerance. The obtained results revealed that HSM-1, HSM-10, HSM-14, and HSM-18 showed high survival rate at different conditions for example low pH, presence of bovine bile and demonstrated high hydrophobicity. Moreover, HSM-14 had an advantage over other strains in terms of gastrointestinal tract tolerance, antimicrobial activities against pathogens, and these results were significantly better than other bacterial candidates.

(Continued on next page)
\end{abstract}

\footnotetext{
* Correspondence: jiayin@hunnu.edu.cn; 201890900001@sdu.edu.cn

${ }^{1}$ Hunan Provincial Key Laboratory of Animal Intestinal Function and Regulation, College of Life Sciences, Hunan Normal University, Changsha,

China

${ }^{3}$ Helmholtz International Lab for Anti-Infectives, Shandong

University-Helmholtz Institute of Biotechnology, State Key Laboratory of

Microbial Technology, Shandong University, Qingdao 266237, China

Full list of author information is available at the end of the article
}

(c) The Author(s). 2020 Open Access This article is licensed under a Creative Commons Attribution 4.0 International License, which permits use, sharing, adaptation, distribution and reproduction in any medium or format, as long as you give appropriate credit to the original author(s) and the source, provide a link to the Creative Commons licence, and indicate if changes were made. The images or other third party material in this article are included in the article's Creative Commons licence, unless indicated otherwise in a credit line to the material. If material is not included in the article's Creative Commons licence and your intended use is not permitted by statutory regulation or exceeds the permitted use, you will need to obtain permission directly from the copyright holder. To view a copy of this licence, visit http://creativecommons.org/licenses/by/4.0/ The Creative Commons Public Domain Dedication waiver (http://creativecommons.org/publicdomain/zero/1.0/) applies to the data made available in this article, unless otherwise stated in a credit line to the data. 
(Continued from previous page)

Conclusion: Hu sheep milk as a source of exploration of potential lactic acid bacteria (LAB) probiotics open the new horizon of probiotics usage from unconventional milk sources. The selected LAB strains are excellent probiotic candidates which can be used for animal husbandry in the future. Rationale of the study was to utilize Hu sheep milk as a source of potential probiotic LABs. The study has contributed to the establishment of a complete bacterial resource pool by exploring the Hu sheep milk microflora.

Keywords: Hu sheep milk, Probiotics, Antimicrobial activity, Cell surface characteristics, Lactococcus lactis, Leuconostoc lactis

\section{Background}

Previous definitions of probiotics emphasized its role in improving gut's microbial ecosystem, suggesting that probiotics are vitally beneficial for the sustainability of intestinal tract and boast immune system [1]. Food and Agriculture Organizations and the World Health Organization, defines probiotics as live microorganisms that confers health benefits on their hosts when ingested in an adequate concentration [2]. In past decades antibiotics abuse has been reported to accelerate drug resistance and evolution of antibiotic resistant strains. Probiotic therapy can be an ideal alternative approach for treating various diseases without getting in the worry of drug resistance. Consumers increasingly needs natural probiotic foods to improve their health and well-being [3]. Lactic acid bacterial strains (LABs) are the members of the our intestinal microbiota and widely being used as probiotics [4]. The most commonly used probiotic Lactobacillus is a member of the normal intestinal microbiota and considered as Generally Recognized As Safe (GRAS) [5]. LABs are widely being used for the elaboration of fermented foodstuffs and increasingly being added to a growing number of foodstuffs such as cheese, yogurt, cereals, fruit, and vegetable juices [6]. LABs form microbial communities and a biological barrier which positively impacted on diarrhea, food allergies, and inflammatory bowel disease $[7,8]$. Lactococcus lactis is one of the oldest domesticated bacterial species and commonly used to make nutritious and healthy foods throughout the world. Due to the current ban of the addition of antibiotics in feeds in China and furtherance of antibiotics free feeds, it has also been modified as an expression host for antimicrobial peptides and proteins, such as many kinds of antibiotics can be modified into a carrier or displayer of oral vaccines. The genus Leuconostoc is Gram-positive, catalase-negative and facultative anaerobes [9]. They can be present in natural food and can also be used as food additives because of their nutritional properties and organoleptic characteristics [10]. Studies have shown that the sensory characteristic properties of goat yogurt can be greatly improved by integrating the cultures of Leuconostoc lactis with traditional yogurt starters [11]. Moreover, Leuconostoc lactis is one of the most important species in the genus Leuconostoc, which plays an important role in the production of glucan and bacteriocin in the food industry $[12,13]$.

The gut microbiota forms a dynamic and diverse community, and certain lactobacilli have been proven to exert health benefits [14]. And the host's treatment of intestinal diseases is also related to probiotics that improve the balance of intestinal flora. For example, treatment of 8-week-old Swiss mice fed a high-fat diet with a mixture of probiotics containing Lactobacillus could significantly change the composition of its intestinal flora and increase insulin sensitivity [15]. Similar studies on obesity indicated that microscopic fungi significantly reduced in the microbiota composition of obese mice treated with Lactobacillus casei and Lactobacillus delbrueckii subsp. bulgaricus [16].

In the cause of being applied as probiotic, each LAB candidate should be probed to ensure the safety and desirability of the strain [17]. During the process of bacterial colonization, first step is the bacterial adhesion to host's tissues, which has always been long expected to be a compelling property among the probiotics [18]. The gastrointestinal tract of animals is considered as the most complex microbial ecosystems, and can affect the absorption and metabolism of nutrients, nutritional and protective functions of the host [19]. Meanwhile, as the normal inhabitants of the healthy gut microbiota, LABs can survive, colonize, and adhere to host tissues. In order to survive, probiotic has to adhere to the intestinal tract and tolerate the presence of bile salts and low intestinal $\mathrm{pH}$. It would also be necessary to check the effect of gastric acid upon reduction of viability of probiotic cells. In addition, spray drying is an economical storage technology being used for probiotics processing, which offers dry and stable powdered form of probiotics and thought to be convenient in transportation which is widely used in dairy industry [20, 21]. However, heat-sensitive cultures have a low survival rate during spray drying procedures [21, 22]. Therefore, it is significant to determine the thermal stability of probiotics and to optimize thermal threshold, which could be cost effective during industrial usage. The heat-resistant 
strain has high survivability ratio and offers a series of industrial advantages [23].

Microbes in milk have been widely reported, but the majority of probiotics in milk samples were also found in human milk or bovine milk [24]. These microorganisms derived from breast milk have the advantage of direct vertical transmission which deserves more in-depth study. Sheep milk have high digestibility, high nutritional quality, low allergenicity, and potential nutraceutical properties [25]. Moreover, sheep milk also provides prebiotic fibers and probiotic bacteria [26, 27]. Hu sheep is a unique local sheep breed in Taihu Plain of China, and among the several white breeds in the world, which has long estrus period, good lactation performance and an average litter size of 2.06 [28], Due to several economic advantages for example fast growth, high productivity rate, good quality meat production, resistance to rough feeding and full house feeding Hu sheep bread is considered to be the first choice for factory producers in China [29]. Gut microorganisms are wildly reported to have a great influence on the growth performance of animals, and maternal milk microbes are the first colonizers in gut of mammalian offspring, which microbes were existed in Hu sheep milk? The aim of the present study was to evaluate potential traits of probiotic strains of three Lactococcus lactis strains (HSM-1, HSM-10, and HSM-18) and one Leuconostoc lactis strain (HSM-14) isolated from $\mathrm{Hu}$ sheep milk through using a series of in vitro tests.

\section{Results}

\section{Screening and identification}

After cultivation of microbes from $\mathrm{Hu}$ sheep milk, we obtained 40 isolates on the basis of their colony morphology and 16S rRNA gene sequences to cover as much diversity as possible at the species level. A phylogenetic tree (Fig. 1a) was constructed using the maximum parsimony analysis with MEGA-X and indicated the relative phylogeny of forty isolates from $\mathrm{Hu}$ sheep milk in comparison to reference strains [30, 31]. Lactococcus lactis

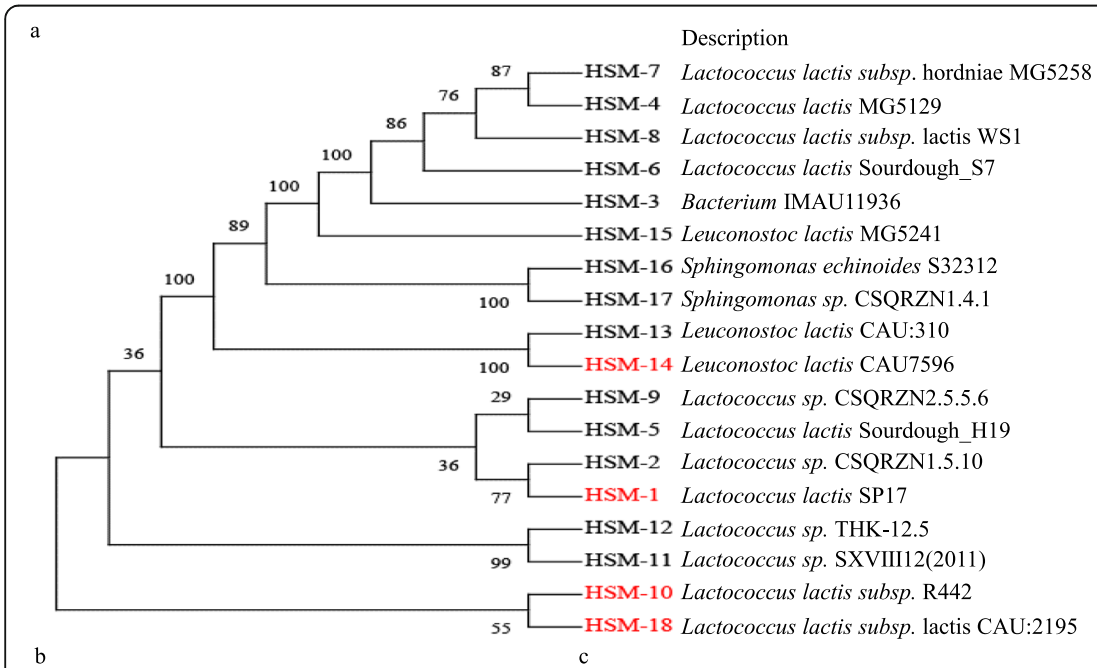

Quary Cover
$100 \%$
$100 \%$
$100 \%$
$100 \%$
$98 \%$
$100 \%$
$88 \%$
$98 \%$
$100 \%$
$96 \%$
$97 \%$
$98 \%$
$99 \%$
$98 \%$
$99 \%$
$98 \%$
$99 \%$
$99 \%$

$\begin{array}{ll}\text { Percent Identity } & \text { Abundances } \\ 100.00 \% & 2 \\ 100.00 \% & 4 \\ 100.00 \% & 11 \\ 100.00 \% & 2 \\ 99.93 \% & 3 \\ 99.92 \% & 1 \\ 91.88 \% & 2 \\ 98.26 \% & 1 \\ 86.74 \% & 2 \\ 99.90 \% & 1 \\ 99.65 \% & 2 \\ 92.86 \% & 2 \\ 97.02 \% & 1 \\ 99.80 \% & 1 \\ 95.79 \% & 1 \\ 95.46 \% & 2 \\ 100.00 \% & 1 \\ 100.00 \% & 1\end{array}$
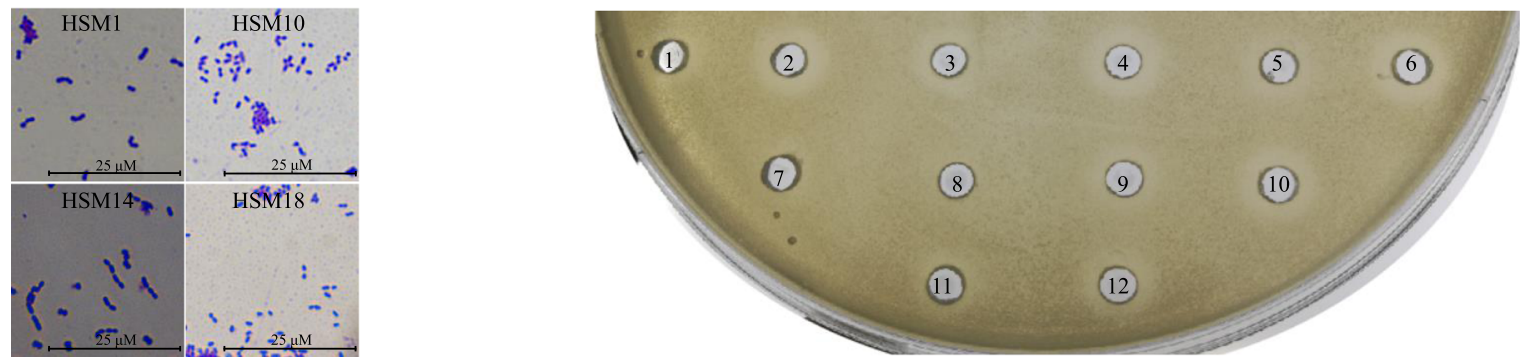

Fig. 1 a The evolutionary history was inferred using the Maximum Parsimony method. The bootstrap consensus tree inferred from 500 replicates is taken to represent the evolutionary history of the taxa analyzed. Branches corresponding to partitions reproduced in less than 50\% bootstrap replicates are collapsed. The percentage of replicate trees in which the associated taxa clustered together in the bootstrap test (500 replicates) are shown next to the branches whereas the BLAST alignment results are showed. The abundances of isolated bacterial are shown in the last column. $\mathbf{b}$ The microscope micrographs of four LAB strains. $\mathbf{c}$ Inhibitory effects of HSM-14 against the pathogen ETEC. The circle wells were filled in different products of HSM-14, including, fermentation broth of cells ( $\mathrm{pH} 3.50)(1 \mathrm{2} 2)$ and cell-free supernatant ( $\mathrm{pH}$ 3.50) without any treatment (3\&4), with 15 min heat inactivation (5\&6), with pH adjusting from 3.5 to 7.5 using $\mathrm{NaOH}$ (7\&8), with the treatment of $1 \mathrm{mg} / \mathrm{mL}$ trypsin (9\&10), and with the treatment of $1 \mathrm{mg} / \mathrm{mL}$ protease $\mathrm{K}$ (11\&12). Some substances $(1,3,5,7,9$ and 11) were obtained from the fermentation broth after cultivation under the aerobic condition while others $(2,4,6,8,10$ and 12$)$ were from the culture under anaerobic condition 
were the most abundant specie in obtained microflora (30/ 40), reflecting the dominance of these species in Hu sheep milk. Minor populations of the other genera such as Leuconostoc lactis (4/40) and Sphingomonas (3/40) were also present in the phylogenetic tree. For further verification, the microscopic pictures of strains were examined (Fig. 1b). In the antimicrobial assay, the four selected strains were used for further delineation as they showed eminent probiotic candidates properties with highest antimicrobial activity against enterohemorrhagic Escherichia coli (EHEC), enterotoxigenic Esherichia coli (ETEC), Staphylococcus aureus, Salmonella typhimurium, Listeria monocytogenes, and Aeromonas caviae (Table 1), while other strains showed weak antibacterial activity against these pathogens. From the selected strains, HSM-1, HSM-10, and HSM-18 are Lactococcus lactis strains while HSM-14 is Leuconostoc lactis strain. Among these four isolates, HSM-14 showed the highest zone of inhibition: $12.5 \pm 3.2,8.2 \pm 1.2,7.9 \pm 1.1$, $7.7 \pm 0.9$, and $7.1 \pm 1.1 \mathrm{~mm}$ against $A$. caviae, $L$. monocytogenes, EHEC, ETEC, and S. aureus, respectively. Meanwhile, the clear inhibition against $S$. typhimurium was showed by HSM-10 with a $7.9 \pm 1.4 \mathrm{~mm}$ inhibition zone. Based on our results, $A$. caviae was recognized as the most sensitive indicator bacteria against the selected LAB species, while $S$. aureus and EHEC showed resistance.

LABs can produce antimicrobial substances, such as bacteriocins, organic acids, and proteins, which are capable of inhibiting the growth of pathogens [32]. Also, the antagonistic activity of LABs is related to the $\mathrm{pH}$ decrease of their growth environment [33]. In order to study the mechanism underlying the antagonistic activity, the fermentation broth of HSM-14 was treated using different methods before conducting the antibacterial assay. The results showed that the antagonistic activity totally disappeared when the $\mathrm{pH}$ value of the supernatant from fermentation broth changed into neutral, but the inhibition zone became visible for the substances obtained from fermentation broth under anaerobic condition (Fig. 1c). This suggested that the organic acids produced by the LABs under anaerobic condition should be probably responsible for the antagonistic activity.

\section{Hydrophobicity of the bacterial surface}

The hydrophobicity assay showed that all the four selected strains had high hydrophobicity (Table 2). The hydrophobicity of HSM-1, HSM-10 and HSM-14 in ndodecane $(97.8 \pm 0.6 \%, 97.9 \pm 1.4 \%$ and $97.1 \pm 0.7 \%$ respectively) and xylene $(92.6 \pm 1.2 \%, 94.6 \pm 1.0 \%$ and $93.4 \pm 1.5 \%$ respectively) which was higher than that in chloroform $(82.5 \pm 5.5 \%, 84.5 \pm 4.0 \%$ and $75.0 \pm 7.1 \%$ respectively), but the hydrophobicity of HSM-18 in chloroform $(97.1 \pm 0.7 \%)$ was higher than that in $\mathrm{n}$-dodecane $(86.8 \pm 3.8 \%)$ and xylene $(84.8 \pm 1.9 \%)$. Therefore, we concluded that HSM-10 possessed the highest hydrophobicity.

\section{Auto-aggregation and co-aggregation}

As shown in Table 2, HSM-1 and HSM-10 showed the best auto-aggregation ability among the selected strains $(59.9 \pm 4.0 \%$ and $63.54 \pm 10.7 \%$, respectively). HSM-14 and HSM-18 exhibited low auto-aggregation ability comparatively ( $16.5 \pm 3.4 \%$ and $23.7 \pm 2.0 \%$, respectively). Additionally, the all four strains showed high coaggregation ability [34] to $S$. aureus $(52.0 \pm 14.9 \%, 35.7 \pm$ $2.3 \%, 51.1 \pm 13.1 \%$ and $52.1 \pm 2.9 \%$, respectively). For $L$. monocytogenes, high co-aggregation [34] was observed in HSM-10 and HSM-14 $(37.6 \pm 8.1 \%$ and $38.1 \pm 10.3 \%$, respectively), followed by HSM-1 and HSM-18 (25.2 \pm $3.8 \%$ and $22.7 \pm 5.0 \%$, respectively). For S. typhimurium, only HSM-14 showed the highest polymerization ability $(28.0 \pm 3.0 \%)$.

\section{Heat treatment}

HSM-1 showed the highest heat resistance, followed by HSM-10 and HSM-14 (Table 2). When LABs were treated at $50{ }^{\circ} \mathrm{C}$ for $5 \mathrm{~min}$, the survival rate of HSM10 (57.5\%) and HSM-14 (32.7\%) was obviously lower than HSM-1 (74.6\%). However, HSM-18 had the lowest rate of heat resistance $(9.0 \%)$. No significant differences were observed relative to the growth of HSM- 1 at $60^{\circ} \mathrm{C}$ and $50{ }^{\circ} \mathrm{C}$ ( $p$-value 0.99). After heat treatment at $60^{\circ} \mathrm{C}, 74.2 \%$ of HSM-1 population survived. However, the survival rate of HSM-10 and HSM-14 declined to 14.4 and $11.6 \%$ respectively. After heat treatment at $70{ }^{\circ} \mathrm{C}$, the survival rate of strains dropped less than $1 \%$. These results indicate that HSM-1 has better heat resistance as compared to the other three strains at $50{ }^{\circ} \mathrm{C}$ or $60^{\circ} \mathrm{C}$.

Table 1 Antimicrobial activity of isolated lactic acid bacteria strains against major foodborne pathogens

\begin{tabular}{|c|c|c|c|c|c|c|}
\hline Strain & S. aureus & EHEC & S. typhimurium & L. monocytogenes & ETEC & A. caviae \\
\hline $\mathrm{HSM}-1$ & $6.1 \pm 0.8^{b}$ & $6.9 \pm 1.3^{a}$ & $7.2 \pm 1.8^{\mathrm{a}}$ & $7.2 \pm 1.8^{\mathrm{ab}}$ & $6.6 \pm 1.0^{b}$ & $7.4 \pm 2.5^{c}$ \\
\hline HSM-10 & $6.0 \pm 0.5^{b}$ & $7.1 \pm 2.0^{a}$ & $7.9 \pm 1.4^{a}$ & $7.8 \pm 2.1^{\mathrm{ac}}$ & $7.7 \pm 1.7^{\mathrm{ac}}$ & $10.2 \pm 1.9^{h}$ \\
\hline HSM-14 & $7.1 \pm 1.1^{\mathrm{a}}$ & $7.9 \pm 1.1^{\mathrm{a}}$ & $7.8 \pm 1.2^{\mathrm{a}}$ & $8.2 \pm 1.2^{\mathrm{ac}}$ & $7.7 \pm 0.9^{\mathrm{a}}$ & $12.5 \pm 3.2^{\circ}$ \\
\hline HSM-18 & $5.4 \pm 0.5^{b}$ & $5.2 \pm 0.6^{b}$ & $6.5 \pm 0.5^{\mathrm{a}}$ & $6.1 \pm 1.9^{b}$ & $6.4 \pm 1.1^{b}$ & $6.2 \pm 0.7^{c}$ \\
\hline
\end{tabular}

Note: Data are mean \pm SD $(n=3)$. Mean values with different superscript letters $(a-c)$ in the same row are significantly different, based on LSD test $(p<0.05)$ 
Table 2 In vitro probiotic properties of isolated lactic acid bacteria strains

\begin{tabular}{|c|c|c|c|c|c|c|c|c|c|c|}
\hline \multirow[t]{2}{*}{ Strain } & \multicolumn{4}{|c|}{ Auto-aggregation and co-aggregation with pathogens } & \multicolumn{3}{|c|}{ Hydrophobicity } & \multicolumn{3}{|c|}{ Heat-treatment } \\
\hline & Auto-aggregation & S. aureus & S. typhimurium & L. monocytogenes & n-Dodecane & Chloroform & Xylene & $50^{\circ} \mathrm{C}$ & $60^{\circ} \mathrm{C}$ & $70^{\circ} \mathrm{C}$ \\
\hline$S \mid \mathrm{VI}-1$ & $59.9 \pm 4.9 \%^{\mathrm{a}}$ & $52.0 \pm 14.9 \%^{\mathrm{a}}$ & $17.1 \pm 6.3 \%^{\mathrm{a}}$ & $25.2 \pm 3.8 \%^{\mathrm{ab}}$ & $97.8 \pm 0.6 \%^{\mathrm{a}}$ & $82.5 \pm 5.5 \%^{\mathrm{b}}$ & $92.6 \pm 1.2 \%^{\mathrm{a}}$ & $74.6 \%{ }^{\mathrm{a}}$ & $74.2 \%^{\mathrm{a}}$ & $0.2 \%^{b}$ \\
\hline 0 & $63.5 \pm 13.1 \%^{\mathrm{a}}$ & $35.7 \pm 2.3 \%^{\mathrm{a}}$ & $16.2 \pm 4.2 \%^{\mathrm{a}}$ & $37.6 \pm 8.1 \%{ }^{\mathrm{ab}}$ & $97.9 \pm 1.4 \%^{\mathrm{a}}$ & $84.5 \pm 4.0 \%^{\mathrm{b}}$ & $94.6 \pm 1.0 \%^{\mathrm{a}}$ & $57.5 \%^{\mathrm{a}}$ & $14.4 \%^{\mathrm{b}}$ & $0.1 \%^{\mathrm{c}}$ \\
\hline HSM-14 & $16.5 \pm 4.1 \%^{\mathrm{b}}$ & $51.1 \pm 13.1 \%^{\mathrm{a}}$ & $28.0 \pm 3.0 \%^{\mathrm{a}}$ & $38.1 \pm 12.7 \%^{\mathrm{a}}$ & $97.1 \pm 0.7 \%^{\mathrm{a}}$ & $75.0 \pm 7.1 \%^{b}$ & $93.4 \pm 1.5 \%^{\mathrm{a}}$ & $32.7 \%^{a}$ & $11.6 \%^{\mathrm{b}}$ & $0.4 \%^{\mathrm{ac}}$ \\
\hline HSM-18 & $23.7 \pm 2.3 \%^{b}$ & $52.1 \pm 2.9 \%^{\mathrm{a}}$ & $14.5 \pm 4.7 \%^{\mathrm{a}}$ & $22.7 \pm 5.0 \%^{b}$ & $86.8 \pm 3.8 \%^{\mathrm{b}}$ & $97.1 \pm 0.7 \%^{\mathrm{a}}$ & $84.8 \pm 1.9 \%^{\mathrm{b}}$ & $9.0 \%^{\mathrm{a}}$ & $0.0 \%^{\mathrm{b}}$ & $0.0 \%^{\mathrm{a}}$ \\
\hline
\end{tabular}

Note: Data are mean $\pm S D(n=3)$. Mean values with different superscript letters $(a-c)$ in the same row are significantly different, based on LSD test $(p<0.05)$

Table 3 The sensitivity of probiotic candidates against 30 antibiotics

\begin{tabular}{|c|c|c|c|c|c|c|}
\hline Types of Drugs & Drug & $\mu \mathrm{g} / \mathrm{pill}$ & $\mathrm{HSM}-1$ & HSM-10 & HSM-14 & HSM-18 \\
\hline \multirow[t]{5}{*}{ Penicillins } & Penicillin & $10 U$ & $39(S)$ & $39(S)$ & $37(S)$ & $38(S)$ \\
\hline & Oxacillin & 1 & $27(S)$ & $19(l)$ & $20(l)$ & $22(S)$ \\
\hline & Carboxycillin & 100 & $42(S)$ & $44(S)$ & $33(S)$ & $40(S)$ \\
\hline & Piperacillin & 100 & $48(S)$ & $29(\mathrm{~S})$ & $37(S)$ & $42(S)$ \\
\hline & Ampicillin & 100 & $31(S)$ & $35(S)$ & $31(S)$ & $32(S)$ \\
\hline \multirow[t]{7}{*}{ Cephalosporins } & Cephalexin & 30 & $33(S)$ & $40(S)$ & $29(S)$ & $28(S)$ \\
\hline & Cefazolin & 30 & $47(S)$ & $25(\mathrm{~S})$ & $27(S)$ & $45(S)$ \\
\hline & Cefradine & 30 & $34(S)$ & $44(S)$ & $27(S)$ & $32(S)$ \\
\hline & Ceftazidime & 30 & $28(S)$ & $44(S)$ & $17(I)$ & $29(S)$ \\
\hline & Cefoperazone & 75 & $41(S)$ & $40(S)$ & $29(S)$ & $37(S)$ \\
\hline & Cefatriaxone & 30 & $41(S)$ & $38(S)$ & $26(S)$ & $35(S)$ \\
\hline & Cefuroxime & 30 & $48(S)$ & $44(S)$ & $36(S)$ & $49(S)$ \\
\hline \multirow[t]{4}{*}{ Aminoglycosides } & Amikacin & 30 & $19(\mathrm{I})$ & $19(l)$ & $11(\mathrm{R})$ & $24(S)$ \\
\hline & Kanamycin & 30 & $25(S)$ & $21(S)$ & $7(\mathrm{R})$ & $20(l)$ \\
\hline & Neomycin & 30 & $22(S)$ & $17(I)$ & $15(\mathrm{R})$ & $20(l)$ \\
\hline & Gentamicin & 10 & $22(S)$ & $14(\mathrm{R})$ & $12(\mathrm{R})$ & $21(S)$ \\
\hline \multirow[t]{3}{*}{ Tetracycline } & Tetracycline & 30 & $14(\mathrm{R})$ & $13(\mathrm{R})$ & $29(S)$ & $14(R)$ \\
\hline & Doxycycline & 30 & $22(S)$ & $22(S)$ & $28(S)$ & $17(I)$ \\
\hline & Minocycline & 30 & $30(S)$ & $27(S)$ & $35(S)$ & $26(S)$ \\
\hline \multirow[t]{2}{*}{ Macrolides } & Erythromycin & 15 & $34(S)$ & $29(S)$ & $28(S)$ & $32(S)$ \\
\hline & Midecamycin & 30 & $34(S)$ & $29(\mathrm{~S})$ & $23(S)$ & $26(S)$ \\
\hline Glycopeptides & Vancomycin & 30 & $31(S)$ & $25(S)$ & $7(\mathrm{R})$ & $26(S)$ \\
\hline \multirow[t]{6}{*}{ Quinolones } & Norfloxacin & 10 & $18(I)$ & $16(l)$ & $29(S)$ & $25(S)$ \\
\hline & Ofloxacin & 5 & $32(S)$ & $27(S)$ & $29(S)$ & $29(S)$ \\
\hline & Ciprofloxacin & 5 & $27(S)$ & $26(S)$ & $22(S)$ & $21(S)$ \\
\hline & Furazolidone & 300 & $23(S)$ & $17(I)$ & $19(l)$ & $29(S)$ \\
\hline & Chloramphenicol & 30 & $39(S)$ & $36(S)$ & $36(S)$ & $36(S)$ \\
\hline & Clindamycin & 2 & $41(S)$ & $37(S)$ & $27(S)$ & $40(S)$ \\
\hline Sulfonamides & Sulfamethoxazole (SMZ/TMP) $\Delta$ & $23.75 / 1.25$ & $17(\mathrm{I})$ & $18(l)$ & $8(\mathrm{R})$ & $20(l)$ \\
\hline Other classes & Polymyxin & $300 \mathrm{IU}$ & $22(S)$ & $5(\mathrm{R})$ & $7(\mathrm{R})$ & $24(S)$ \\
\hline
\end{tabular}

Note: The zone of inhibition (diameter in $\mathrm{mm}$ ) for each antibiotic was measured and expressed as susceptible, $\mathrm{S}(\geq 21 \mathrm{~mm})$; intermediate, I (16-20 $\mathrm{mm})$, and resistance, $\mathrm{R}(<=15 \mathrm{~mm})$ 


\section{Antibiotic susceptibility assay}

The susceptibility of four LABs was also evaluated against 30 antibiotics of nine different classes, which were sorted in line accordance with their resistance profile to the tested drugs (Table 3) [35]. None of the strains tested were sensitive to all antibiotics [35]. HSM1 was resistant to Amikacin, Tetracycline, Norfloxacin, and Sulfamethoxazole. HSM-10 exhibited resistance to 9 antibiotics and HSM-14 exhibited resistance to 10 antibiotics. HSM-18 was not sensitive to Kanamycin, Neomycin, Tetracycline, Doxycycline, and Sulfamethoxazole.

\section{Growth at different bile salts concentrations and low $\mathrm{pH}$}

The selected LABs strains were incubated at $37^{\circ} \mathrm{C}$ for $12 \mathrm{~h}$ in MRS at a variable $\mathrm{pH}$ range of 2.0, 3.0 and 4.0 to determine the acid tolerance (Fig. 2a). They showed certain viability under low pH. HSM-1, HSM-10, HSM-14 and HSM-18 grown best under the condition of MRS at pH 4.0 (27.33, 24.27, 25.22 and $23.75 \%$, respectively). The survival rate ranged from 8 to $9 \%$ under the condition of MRS with adjusted $\mathrm{pH}$ of 3.0 and was $6-7 \%$ under the condition of MRS with adjusted $\mathrm{pH}$ of 2.0. To estimate bile tolerance, four strains were treated with $0.1,0.3$ and $0.5 \%$ of bovine choline and incubated at $37^{\circ} \mathrm{C}$ for $12 \mathrm{~h}$. All these four strains exhibited resistance to different concentrations of bovine choline. The bacterial viability decreased with the increase of bovine choline (Fig. 2b). In summary, HSM-1, HSM-10, HSM-14 and HSM-18 had the ability to grow and survive at low $\mathrm{pH}$ and in the presence of bovine bile, demonstrating that these strains could tolerate gastrointestinal environmental conditions.

\section{Resistance to simulated gastric and intestinal conditions}

Survival of the four LABs after $3 \mathrm{~h}$ of SGJ treatment and $4 \mathrm{~h}$ of simulated pancreatic juice treatment were showed in Fig. 2c. These four LABs demonstrated the high survival rates after $3 \mathrm{~h}$ cultivation in the SGJ [36]. As expected, the results revealed that the survival rate of the four LABs decreased with the increase of treatment time. At pH 3.0, the survival rates of HSM-1 and HSM10 increased by $0.125 \log 10 \mathrm{CFU} / \mathrm{mL}$ and $0.064 \log 10$ $\mathrm{CFU} / \mathrm{mL}$, which showed their survival rates were higher than $100 \%$, while the viability of HSM-14 and HSM-18 decreased by $0.012 \log _{10} \mathrm{CFU} / \mathrm{mL}$ and $0.065 \log _{10}$ $\mathrm{CFU} / \mathrm{mL}$. Besides, all four LABs have decreased their populations in the SIJ [37]. After $4 \mathrm{~h}$ exposure to the SIJ, HSM-1 decreased the most, about $3.208 \log _{10} \mathrm{CFU} / \mathrm{mL}$,

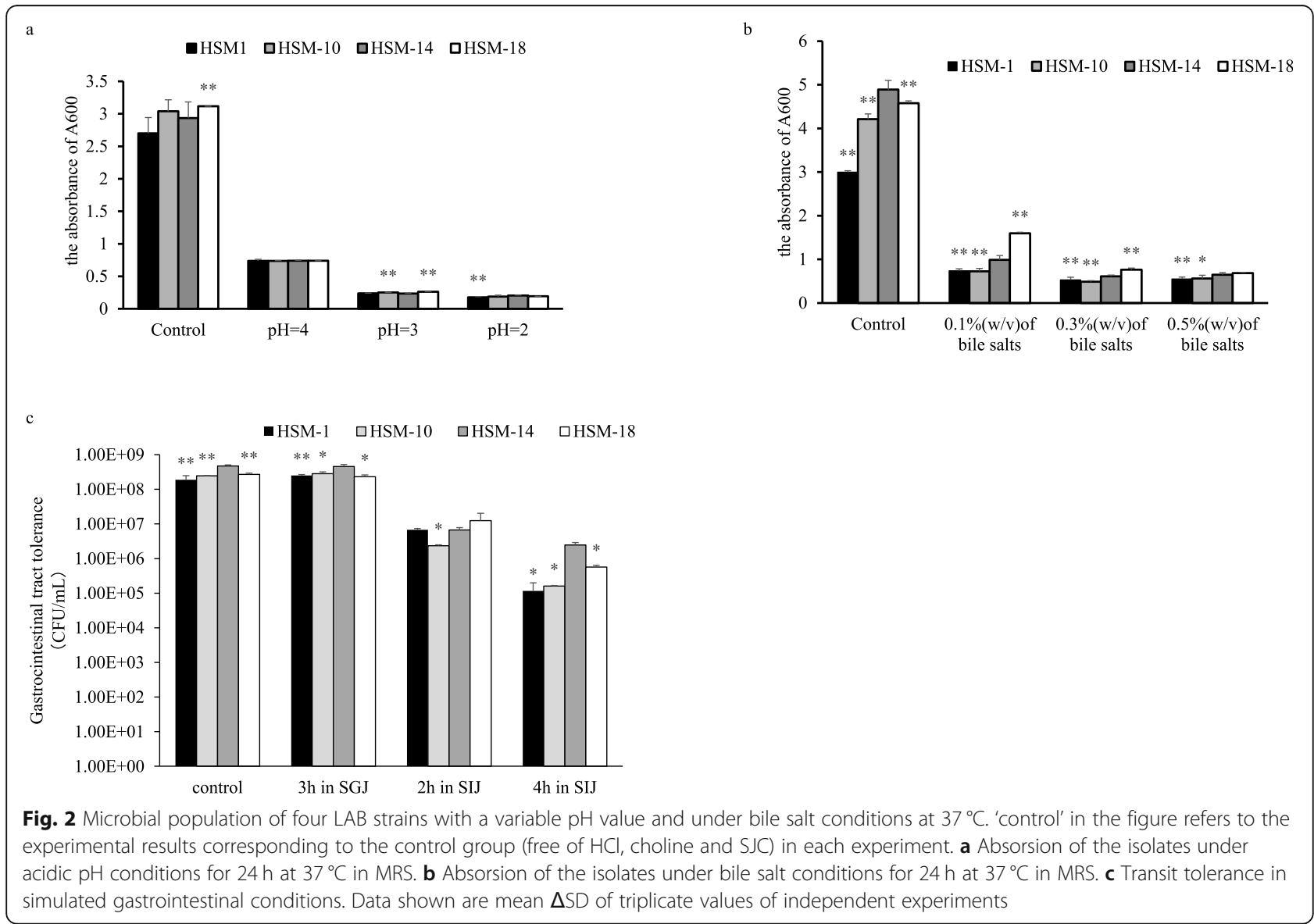


followed by HSM-10 decreased by $3.186 \log _{10} \mathrm{CFU} / \mathrm{mL}$. HSM-14 and HSM-18 decreased by $2.28 \log _{10} \mathrm{CFU} / \mathrm{mL}$ and $2.674 \log _{10} \mathrm{CFU} / \mathrm{mL}$ respectively. HSM-1 was found to be most tolerant to bile salts that is about 2.28 $\log _{10} \mathrm{CFU} / \mathrm{mL}$. These four strains might become potential probiotic candidates. In view of the different survival rates, the smallest variation trend of HSM-14 indicated that it had the strongest survival ability and resistance in the simulated gastrointestinal environment.

\section{Discussion}

In current study, we focused on the LABs with potential probiotic functions explored from $\mathrm{Hu}$ sheep milk. The increase in multidrug resistant organisms compromised the therapies of a growing number of infectious diseases for decades [38]. Thus, it is necessary and urgent to find new alternatives which are more effective against antibiotic resistant pathogens. In this study, different food borne pathogens for example $S$. aureus, ETEC, EHEC, $S$. typhimurium, L. monocytogen, and A. caviae were studied and had been found to be associated with certain gastrointestinal diseases including gastrointestinal infections [39]. Among the selected strains, HSM-14 showed the highest zones of inhibition against above mentioned pathogens.

Cellular hydrophobicity is the premise for probiotics to exert the beneficial effect of probiotics by eliminating intestinal pathogens, adhere to intestinal epithelial cells, and colonize the gastrointestinal tract [40]. In addition, the ability of cells to auto-aggregate makes a significant contribution of adherence to intestinal cells and avoids pathogens colonization. Co-aggregation ability of bacteria eliminates gastrointestinal pathogens by preventing them from adhering to host tissues. Potential probiotics should have the ability to colonize the intestinal tract and prevent the colonization of pathogenic bacteria [32]. HSM-1, HSM-10, HSM-14, and HSM-18 had high hydrophobic capacity. The co-aggregation scores of HSM-1, HSM-10, and HSM-18 with the pathogen $S$. aureus exceeded $50 \%$, and the effect was better than $S$. typhimurium and L. monocytogenes.

Safety is also a significant consideration while selecting potential probiotics before they are available in the market for public usage [41, 42]. We evaluated the antibiotic resistance of LABs from Hu sheep milk. The results of antibiotics sensitivity showed that different antibiotics had different effects on the selected isolates. The risk of dissemination of resistant genes to other microorganisms is increasing, and potential probiotic strains should not have transferrable antibiotic resistance [1]. We will screen virulence genes and resistance genes in potential probiotics strains to further evaluate the safety of strains in the near future.
Survival and growth at low $\mathrm{pH}$ and in the presence of bovine bile are also desirable characteristics for potential probiotics strains. Human large intestine contains bile salt, whose concentration varies between $0.3 \% \sim 0.5 \%$. Generally, the $\mathrm{pH}$ of gastric juice depends on the time of feeding, diet and it may vary from 1.5 to 4.5 [43, 44]. Growth and survival at low $\mathrm{pH}$ and in the presence of bovine bile are thought to be the most desirable characteristics for future probiotic strains. Probiotics need to be survival in the small intestine through acidic environment of the stomach and alkaline environment of the colon resisting bile salt. The $\mathrm{pH}$ of gastric juice is around 3.0, and the stomach gastric digestion can last for $3 \mathrm{~h}$ [14]. According to the previous study [45], the $\mathrm{pH}$ of 3.0, for $3 \mathrm{~h}$ was reported as the standard for screening probiotics for acid resistance. The physiological concentration of human bile ranges between 0.3 and $0.5 \%$, the time for food to pass through the small intestine is about $4 \mathrm{~h}$, and the average concentration of bile is $0.3 \%$. By simulating the gastrointestinal environment and comparing the low $\mathrm{pH}$ environment with the high bile concentration environment, the feasibility of the experimental strain as a probiotic was also evaluated. The results indicated that HSM-1, HSM-10, HSM-14, and HSM-18 were resistant to low $\mathrm{pH}$ and high bile acid concentrations. Moreover, HSM-14 had the highest survival rate as compared to any of the other three strains in the experiments, and resistant to simulated gastric and intestinal conditions. The results showed that HSM14 could be a promising probiotic candidate.

During heat drying processing of probiotics, a large number of probiotics bacteria dies because of their less thermal stability. During the pasteurization, milk sample should be under heat-treatment for a certain time. Pasteurization is a common method that used to eliminate the milk borne pathogens. It has shown that pasteurization can reduce the number of microorganisms in milk by about 20 times [46]. Holder pasteurization $\left(62.5^{\circ} \mathrm{C}, 30 \mathrm{~min}\right)$ is the most widespread method of milk processing at comparatively low temperature [47]. The typical treatment for pasteurization is the high temperature short duration method, where milk is heated to $72^{\circ} \mathrm{C}$ for $15 \mathrm{~s}$ [46]. Therefore, in this heat resistance experiment, we chose a maximum temperature of $70^{\circ} \mathrm{C}$ to explore the prospect of four LABs in industrial applications, including pelletizing and storage.

After the treatment at $70^{\circ} \mathrm{C}$, the survival rate of the isolates was less than $1 \%$, and the heat resistance effect of HSM-18 was the worst. Adding certain substances can enhance the heat resistance of LABs, such as recombinant skim milk [48]. The heavy fat skimmed milk is rich in calcium, which can promote the growth of LABs and also improve the thermal stability of cell envelope protease. 
These tests enabled a preliminary selection of strains having probiotic potentials, which can resist gastrointestinal conditions, and also have antibacterial effects on harmful bacteria. These trials are preliminary steps of a large number of assays devoted to select and characterize probiotic Lactobacillus strains as alternatives to antibiotics and aimed to decrease antibiotics usage to treat gastrointestinal diseases and stabilize the balance of intestinal microbial microbiota. We will screen certain virulence and resistance genes in potential probiotics strains to further evaluate the safety of strains in the future.

\section{Conclusions}

In the present study, four LABs isolated from Hu sheep milk, HSM-1, HSM-10, HSM-14, and HSM-18, were found to have potential probiotic candidates' properties. We evaluated these LAB strains through using a series of in vitro experiment for detecting probiotic candidate's properties, which can be raised for the production of various kinds of food and pharmaceutical products. It was worth noting that HSM-14 had prominent advantages over other strains in terms of gastrointestinal tract tolerance and antimicrobial activities against pathogens, and it was believed to be the best candidate for potential LAB probiotics. It was suggested that the LABs procured might be used as bio-therapeutics against bacterial infection to humans. Our isolate is a potential candidate for application such as novel probiotic isolates which is used for human or animal food processing and drug production in the future. Nevertheless, further investigations are needed to evaluate the isolates in vivo and to assess the technical characteristics.

\section{Methods}

\section{Screening and identification}

According to instructions and consultants from experimental farm of $\mathrm{Hu}$ sheep (Yichang, China), the milk samples were collected aseptically and brought cooled to the laboratory. The Hu sheep milk samples were inoculated into MRS broth (OXOID Co., Ltd. Shanghai, China) and cultivated for 3 days at $37^{\circ} \mathrm{C}$ under anaerobic conditions [49]. Identification of the isolates at genus level was carried out by using morphological and phenotypic methods. White and cocci shaped bacterial colonies were selected and further subjected to sub culturing on MRS agar (OXOID Co., Ltd. Shanghai, China) to obtain pure bacterial culture [50]. All isolates were stored at $-80^{\circ} \mathrm{C}$ with $50 \%(\mathrm{v} / \mathrm{v})$ glycerol and designated as HSM1 to HSM40. DNAs of the selected 40 strains were extracted and $16 \mathrm{~s}$ rRNA gene were amplified using the universal primers $27 \mathrm{~F}$ (5'-AGAGTTTGATCM TGGCTCAG-3') and 1492R (5'-GGTTACCTTG TTACG ACTT-3') [51]. The PCR amplified products were sequenced by using Sanger sequencing (Sangon Biotech Ltd., China) and blast against NCBI nucleotide collection (nr/nt) database using BLASTN. The nearest match for each sequence was extracted, and taxonomy was assigned up to the species level. We counted the number of sequences assigned to unique species for subsequent analysis. The phylogenetic tree was constructed by using Maximum Parsimony (MP) model of software MEGA-X.

\section{Antimicrobial activity}

Antimicrobial activity assays were determined using the agar well diffusion assay, as suggested by the previous study [52]. LABs were grown in MRS broth at $37^{\circ} \mathrm{C}$ for $18 \mathrm{~h}$, and pathogenic bacteria including S. aureus ATCC 25923, EHEC O157:H7 ATCC 43894, ETEC O149:K88 W25K [53], L. monocytogenes ATCC 19113, S. typhimurium ATCC 14028, and A. caviae ATCC 15468) were grown in LB broth (Sangon Biotech, Co., Ltd. Shanghai, China) at $37^{\circ} \mathrm{C}$ for $12 \mathrm{~h}$ in an aerobic condition. Pathogenic bacteria were serially diluted with LB liquid medium up to 200 times and then flooded on LB agar plates and were kept at room temperature for $20 \mathrm{~min}$ for drying. Five wells were prepared in each agar plate by using a depth of $6 \mathrm{~mm}$ and a diameter of $5 \mathrm{~mm}$ sterile iron pipette. Precisely, $30 \mu \mathrm{L}$ of LAB culture were added to each well, and one remaining well was filled with $30 \mu \mathrm{L}$ of MRS broth as the negative control. These plates were then incubated in an aerobic condition at $37^{\circ} \mathrm{C}$ for $24 \mathrm{~h}$. After incubation, the zone of inhibition (ZOI) was measured by length meter, and the experiment was repeated at least three times.

\section{Hydrophobicity of the bacterial surface}

The hydrophobicity of the bacterial surface was determined by the Microbial Adhesion to Hydrocarbon (MATH) assay [54]. Bacterial hydrophobicity was measured through using different organic solvents such as n-dodecane (Aladdin Co., Ltd. Shanghai, China), xylene (Sinopharm Chemical Reagent Co., Ltd. Shanghai, China), and chloroform (Sinopharm Chemical Reagent Co., Ltd. Shanghai, China). The LABs were grown in MRS broth at $37^{\circ} \mathrm{C}$ for $24 \mathrm{~h}$. Bacterial cell suspensions were then harvested by centrifugation at $6000 \mathrm{rpm}$ for $10 \mathrm{~min}$ at $4{ }^{\circ} \mathrm{C}$ and washed twice with PBS (BBI Life Sciences Co., Ltd. Shanghai, China), which was resuspended in PBS $(\mathrm{pH}=7.2)$ for an Optical Density (OD ${ }_{600} \mathrm{~nm}$ ) of 0.8 . One milliliter of $\mathrm{n}$-dodecane, xylene or chloroform was added to $3 \mathrm{~mL}$ of bacterial cell suspension in a separate test tube, and vortexed for $120 \mathrm{~s}$. The tubes were kept for $20 \mathrm{~min}$ at room temperature to separate the organic and aqueous phases. Later, the organic phase was removed, and the absorbance of the aqueous phases was determined at $600 \mathrm{~nm}$, while PBS was used as a control. 
The experiment was repeated for three times, and the hydrophobicity percentage was determined as follows:

$$
\text { Hydrophobicity }(\%)=\left[\left(\mathrm{A}_{0}-\mathrm{A}_{\mathrm{t}}\right) / \mathrm{A}_{0}\right] \times 100 \%
$$

$A_{0}$ represents the value of $O_{600}$ before mixing. $A_{t}$ stands for the value of $\mathrm{OD}_{600}$ after mixing. The degree of bacterial hydrophobicity was classified as low (0$29 \%)$, medium (30-59\%) or high (60-100\%) [54].

\section{Auto-aggregation assay}

Auto-aggregation assay was determined according to the previously reported method [55], with slight modifications. LABs were grown in MRS broth for $24 \mathrm{~h}$ at $37^{\circ} \mathrm{C}$. Then bacteria were harvested by centrifugation at 6000 rpm for $10 \mathrm{~min}$ at $4{ }^{\circ} \mathrm{C}$. The harvested cells were then washed twice and resuspended in PBS $(\mathrm{pH}=7.2)$ to achieve the $\mathrm{OD}_{600}$ of 0.8 . Four milliliters of the bacterial suspensions were vortexed for $120 \mathrm{~s}$ and incubated at room temperature for $5 \mathrm{~h}$. One milliliter of the above suspension was carefully taken up and the $\mathrm{OD}_{600}$ was determined. The experiment was repeated three times and auto-aggregation was calculated as follows:

$$
\text { Auto - aggregation }(\%)=1-\mathrm{A}_{\mathrm{t}} / \mathrm{A}_{0} \times 100 \%
$$

$A_{t}$ represents the value of $O_{600}$ at time $t=5 \mathrm{~h} ; \mathrm{A}_{0}$ indicates the value of $\mathrm{OD}_{600}$ at $\mathrm{t}=0 \mathrm{~h}$.

\section{Co-aggregation assay}

Co-aggregation assay was evaluated according to previously reported method [56]. Bacterial suspensions of LAB and pathogenic bacteria (S. aureus ATCC 25923, $S$. typhimurium ATCC 14028, and L. monocytogenes ATCC 19113) were prepared same as for auto-aggregation analysis. Equal volumes $(2 \mathrm{~mL})$ of each LAB and pathogenic bacteria cell suspensions were mixed and incubated at room temperature for $5 \mathrm{~h}$ without agitation. Control tubes containing $4 \mathrm{~mL}$ of single bacterial suspensions were also incubated under the same growth condition, and the $\mathrm{OD}_{600}$ was measured. The experiment was repeated for three times and the calculation formula for co-aggregation was addressed as follows:

$$
\text { Co- aggregation }(\%)=\left[\left(\mathrm{A}_{\mathrm{x}}+\mathrm{A}_{\mathrm{y}}\right) / 2-\mathrm{A}_{(\mathrm{x}+\mathrm{y})}\right] /\left(\mathrm{A}_{\mathrm{x}}+\mathrm{A}_{\mathrm{y}}\right) \times 100 \%
$$

Where $A_{x}$ and $A_{y}$ represent the absorbance of the two bacteria cell suspensions and $A_{(x+y)}$ means the absorbance of mixed bacteria cell suspensions.

\section{Heat treatment}

The LAB strains after $18 \mathrm{~h}$ cultivation in MRS broth were concentrated to $1.0 \mathrm{ml}$ cell suspension and kept at the different temperatures of $37^{\circ} \mathrm{C}, 50^{\circ} \mathrm{C}, 60^{\circ} \mathrm{C}$, and $70^{\circ} \mathrm{C}$, respectively, for $5 \mathrm{~min}$. The numbers of living cells were determined in terms of CFU. $\mathrm{mL}^{-1}$. Each experiment was repeated three times to calculate the mean, the calculation formula for survival was as follows:

$$
\text { Survival }(\%)=\mathrm{CFU} \cdot \mathrm{mL}^{-1}(\mathrm{t}) \times 100 / \mathrm{CFU} \cdot \mathrm{mL}^{-1}\left(\mathrm{t}_{0}\right)
$$

t stands for $50^{\circ} \mathrm{C}, 60^{\circ} \mathrm{C}$, and $70^{\circ} \mathrm{C}$ while $t_{0}$ representss for $37^{\circ} \mathrm{C}$.

\section{Antibiotic susceptibility assay}

Antibiotic susceptibility assay of LAB isolates was performed on MRS agar via disc diffusion method [57]. At first, $\mathrm{LAB}$ isolates were grown in MRS broth at $37^{\circ} \mathrm{C}$ to achieve the $\mathrm{OD}_{600}$ of 0.8 . Then, LABs were added to the semi-solidified MRS medium and diluted at a ratio of 20,000 times. Next, they were shaked gently and poured into petri plate for solidification at room temperature. Antibiotics (Hangzhou Mirobial Reagent Co, Ltd) used in the test include penicillin (P, $10 \mathrm{U} / \mathrm{disc})$, oxacillin (OX, $1 \mu \mathrm{g} /$ disc), carboxycillin $(\mathrm{CB}, 100 \mu \mathrm{g} /$ disc), piperacillin (PIP, $100 \mu \mathrm{g} /$ disc), ampicillin (AM, $100 \mu \mathrm{g} / \mathrm{disc}$ ), cephalexin (CA, $30 \mu \mathrm{g} /$ disc), cefazolin $(\mathrm{CZ}, 30 \mu \mathrm{g} / \mathrm{disc})$, cefradine (RAD, $30 \mu \mathrm{g} /$ disc), ceftazidime (CAZ, $30 \mu \mathrm{g} /$ disc), cefoperazone (CFP, $75 \mu \mathrm{g} /$ disc), amikacin (AK, $30 \mu \mathrm{g} / \mathrm{disc}$ ), kanamycin (K, $30 \mu \mathrm{g} / \mathrm{disc})$, neomycin ( $\mathrm{N}$, $30 \mu \mathrm{g} / \mathrm{disc}$ ), gentamicin (GM, $10 \mu \mathrm{g} / \mathrm{disc})$, tetracycline (TE, $30 \mu \mathrm{g} / \mathrm{disc}$ ), doxycycline (DX, $30 \mu \mathrm{g} /$ disc), minocycline (MI, $30 \mu \mathrm{g} / \mathrm{disc})$, erythromycin $(\mathrm{E}, 15 \mu \mathrm{g} / \mathrm{disc})$, midercamycin (MD, $30 \mu \mathrm{g} / \mathrm{disc}$ ), vancomycin (VA, $30 \mu \mathrm{g} /$ disc), norfloxacin (NOR, $10 \mu \mathrm{g} / \mathrm{disc}$ ), ofloxacin (OFX, $5 \mu \mathrm{g} / \mathrm{disc}$ ), ciprofloxacin (CIP, $5 \mu \mathrm{g} / \mathrm{disc}$ ), furazolidone (FZ, $300 \mu \mathrm{g} / \mathrm{disc}$ ), chloramphenicol (C, $30 \mu \mathrm{g} / \mathrm{disc})$, clindamycin (CC, $2 \mu \mathrm{g} / \mathrm{disc}$ ), cefatriaxone (CTR, $30 \mu \mathrm{g} / \mathrm{disc}$ ), cefuroxime (CXM, $30 \mu \mathrm{g} / \mathrm{disc}$ ), sulfamethoxazole (SXT, $23.75 / 1.25 \mu \mathrm{g} /$ disc), and polymyxin (PB, $300 \mathrm{IU} /$ disc). At last, antibiotic discs were placed on medium surface and then LAB strains were incubated anaerobically at $37^{\circ} \mathrm{C}$ for 24 to $48 \mathrm{~h}$. After incubation, diameter of transparent zones was measured and to make the experiment statistically significant it was repeated three times. The results were compared with the values designated by the Clinical and Laboratory Standards Institute.

\section{Growth at different bile salts test and growth at low pH}

The tolerance ability of the strains to bile salt and low $\mathrm{pH}$ environment were conducted following Ramila Azat method [58]. Cells of the selected strains were grown in MRS broth for $12 \mathrm{~h}$ at $37^{\circ} \mathrm{C}$. The freshly grown culture of strain $(4 \%, \mathrm{v} / \mathrm{v})$ was inoculated in MRS broth containing $0,0.1,0.3$, and $0.5 \%(\mathrm{w} / \mathrm{v})$ of bile salts under anaerobic conditions (Huayuehang Instrument Co., Ltd. Guangdong Province, China) for $12 \mathrm{~h}$ at $37^{\circ} \mathrm{C}$. The method used to evaluate the proliferation of the strains at low $\mathrm{pH}$ was similar to the above protocol. Cells of the 
selected strains were grown in MRS broths with variable $\mathrm{pH}$ values of 2.0, 3.0, and 4.0. The different $\mathrm{pH}$ solutions were adjusted by adding $1 \mathrm{M} \mathrm{HCl}$ (Sangon Biotech Co., Ltd. Shanghai, China) under anaerobic conditions for 12 h at $37{ }^{\circ} \mathrm{C}$. The $\mathrm{OD}_{600}$ was measured and calculated in comparison with the control group (choline free, $\mathrm{HCl}$ free). The experiment calculation formula was as follows:

$$
\text { Survival }(\%)=\mathrm{OD}_{600}(\text { experiment }) \times 100 \% / \mathrm{OD}_{600}(\text { control })
$$

\section{Resistance to simulated gastric and intestinal conditions} In order to determine the tolerance of LABs in the simulated gastric and intestinal conditions, the adaptation of the four LAB strains were assessed in vitro according to the reported method [59]. In short, simulated gastric juice (SGJ) was made by dissolving $3.0 \mathrm{~g}$ pepsin (BBI Life Sciences Co., Ltd. Shanghai, China) (from Porcine Stomach BC Grade) in one liter sterile saline solution $(0.9 \%$, $\mathrm{w} / \mathrm{v}$ ), and the $\mathrm{pH}$ was adjusted to 3.0 by using sterile 1 $\mathrm{M} \mathrm{HCl}$. Simulated intestinal juice (SIJ) was formulated by the addition of $0.3 \mathrm{~g} / \mathrm{L}$ bile salts (Sigma, USA) and $1.0 \mathrm{~g} / \mathrm{L}$ trypsin (Sinopharm Chemical Reagent Co., Ltd. Shanghai Province, China) in sterile saline solution $(0.9 \%, \mathrm{w} / \mathrm{v})$, and the $\mathrm{pH}$ was adjusted to 3.0 by using sterile $1 \mathrm{M} \mathrm{NaOH}$ (Sangon Biotech Co., Ltd. Shanghai, China). The prepared solution was filtered using $0.45 \mathrm{~nm}$ filter membrane (Sangon Biotech Co., Ltd. Shanghai, China). LABs were continuously activated for $18 \mathrm{~h}$ in MRS broth at $37^{\circ} \mathrm{C}$. One milliliter of bacterial cell suspension was harvested by centrifugation at $3000 \times \mathrm{g}$ for $10 \mathrm{~min}$ at $4{ }^{\circ} \mathrm{C}$ and dissolved in MRS broth $(500 \mu \mathrm{l})$ and SGJ $(500 \mu \mathrm{l})$ miscible liquids, and incubated at $37^{\circ} \mathrm{C}$ for $2 \mathrm{~h}$ at $300 \mathrm{rpm}$ and then the bacteria were resuspended in SIJ and incubated in the same condition for $4 \mathrm{~h}$. The cell suspensions were incubated at $37^{\circ} \mathrm{C}$ for $0,3,5$, and $7 \mathrm{~h}$ and then cultivated on the MRS agar for $24 \mathrm{~h}$. Then, the number of viable cells was estimated. $\log _{10} \mathrm{CFU} / \mathrm{mL}$ reduction was determined by the difference of $0,3,5$, and $7 \mathrm{~h} \log _{10} \mathrm{CFU} / \mathrm{mL}$.

\section{Statistical analysis}

All the results (except heat-treatment) were presented as the mean value and standard deviation of three replicates. Statistical analysis was performed using SPSS software (v22.0 for Windows; IBM Corp.). For antimicrobial activity, the data was subjected to a LSD (L) test, the mean value was separated using Duncan's multiplerange test, and statistical significance was defined as $p<$ 0.05 .

\section{Abbreviations}

16SrRNA: 165 ribosomal ribonucleic acid; CFU/ml: Colony forming unit per millilitre; LAB: Lactic acid bacteria; PCR: Polymerase chain reaction;
OD: Optical density; DNA: Deoxyribonucleic; EHEC: Enterohemorrhagic E. coli O157:H7 ATCC 43894; ETEC: Enterotoxigenic Escherichia coli O149:K88 W25K; S. aureus: Staphylococcus aureus; S. typhimurium: Salmonella typhimurium; L. monocytogenes: Listeria monocytogenes; A. caviae: Aeromonas caviae; MRS: De Man, Rogosa an Medium (Modified MRS Medium Base); LB: Luria-Bertani; SGJ: Simulated gastric juice; SGJ: Simulated gastric juice; Log ${ }_{10}$ CFU/ $\mathrm{mL}$ : Denary logarithm of Colony forming unit per millilitre

\section{Acknowledgments}

The authors thank Chunpeng Dai (Huanghua Town, Yiling country, Hubei Province) for his assistance of the ewe's milk collection.

\section{Authors' contributions}

JY2 and QT contributed in conceiving and designing the experiments. HY and QW collected milk samples. YL1 and JY1 performed the data analysis. TC and JY1 prepared the manuscript. LH and YZ conducted cell surface characteristics. TC, TAK and LW conducted the simulated transport tolerance in the gastrointestinal tract and acid/bile tolerance experiments. CT, QL and MNA conducted heat treatment and antibiotic susceptibility experiments. YL2 and TY conducted antimicrobial activity experiment. JY2, QT and YY revised the manuscript. All authors listed have made substantial, direct, and intellectual contributions to the work and have approved its publication.

\section{Funding}

This work was supported by the National Natural Science Foundation of China (31700004), Hunan Provincial Science and Technology Department (2019RS5001), Construction of Innovative Provinces in Hunan Province (2019RS3022), Shandong Key Research and Development Program (2019QYTPY002, 2019JZZY010724), the National Students Platform for Innovation and Entrepreneurship Training Program $(201610542011$, 2020056) and Hunan Province College Students Research Learning and Innovative Experiment Project (201910541278). The funding bodies had no contribution in the study design, data collection, interpretation, or preparation of the manuscript.

Availability of data and materials

Data sharing is not applicable to this article as no datasets were generated or analysed during the current study.

Ethics approval and consent to participate Not applicable.

Consent for publication Not applicable.

\section{Competing interests}

The authors declare that the research was conducted in the absence of any commercial or financial relationships that could be construed as a potential conflict of interest.

\section{Author details}

'Hunan Provincial Key Laboratory of Animal Intestinal Function and Regulation, College of Life Sciences, Hunan Normal University, Changsha, China. ${ }^{2}$ Hunan International Joint Laboratory of Animal Intestinal Ecology and Health, College of Life Science, Hunan Normal University, Changsha 410081, China. ${ }^{3}$ Helmholtz International Lab for Anti-Infectives, Shandong University-Helmholtz Institute of Biotechnology, State Key Laboratory of Microbial Technology, Shandong University, Qingdao 266237, China.

${ }^{4}$ Institute of Genetics and Developmental Biology, the Innovation Academy for Seed Design, Chinese Academy of Sciences, Beijing, China. ${ }^{5}$ Chinese Academy of Science, Institute of Subtropical Agriculture, Research Center for Healthy Breeding of Livestock and Poultry, Hunan Engineering and Research Center of Animal and Poultry Science and Key Laboratory for Agroecological Processes in Subtropical Regions, Ministry of Agriculture, Changsha, China. 
Received: 16 April 2020 Accepted: 21 July 2020

Published online: 28 July 2020

\section{References}

1. Adetoye A, Pinloche E, Adeniyi BA, Ayeni FA. Characterization and antisalmonella activities of lactic acid bacteria isolated from cattle faeces. BMC Microbiol. 2018;18(1):96.

2. Who F. Health and nutritional properties of probiotics in food including powder milk with live lactic acid bacteria; 2001.

3. Xiong L, Ni X, Niu L, Zhou Y, Wang Q, Khalique A, Liu Q, Zeng Y, Shu G, Pan $\mathrm{K}$, et al. Isolation and preliminary screening of a Weissella confusa strain from giant panda (ailuropoda melanoleuca). Probiotics Antimicrob Proteins. 2019;11(2):535-44.

4. Elshaghabee FMF, Rokana N, Gulhane RD, Sharma C, Panwar H. Bacillus as potential probiotics: status, concerns, and future perspectives. Front Microbiol. 2017;8:1490.

5. Chen Z, Wang Z, Ren J, Qu X. Enzyme mimicry for combating bacteria and biofilms. Acc Chem Res. 2018;51(3):789-99.

6. Gotteland M, Cires MJ, Carvallo C, Vega N, Ramirez MA, Morales P, Rivas P, Astudillo F, Navarrete P, Dubos C, et al. Probiotic screening and safety evaluation of Lactobacillus strains from plants, artisanal goat cheese, human stools, and breast milk. J Med Food. 2014;17(4):487-95.

7. Guan X, Xu Q, Zheng Y, Qian L, Lin B. Screening and characterization of lactic acid bacterial strains that produce fermented milk and reduce cholesterol levels. Braz J Microbiol. 2017;48(4):730-9.

8. Zhong $L$, Zhang $X$, Covasa M. Emerging roles of lactic acid bacteria in protection against colorectal cancer. World J Gastroenterol. 2014;20(24): 7878-86.

9. Kim J, Chun J, Han HU. Leuconostoc kimchii sp. nov., a new species from kimchi. Int J Syst Evol Microbiol. 2000;50(Pt 5):1915-9.

10. Eom HJ, Seo DM, Han NS. Selection of psychrotrophic Leuconostoc spp. producing highly active dextransucrase from lactate fermented vegetables. Int J Food Microbiol. 2007;117(1):61-7.

11. De Santis D, Giacinti G, Chemello G, Frangipane MT. Improvement of the sensory characteristics of goat milk yogurt. J Food Sci. 2019;84(8):2289-96.

12. Hwang IC, Oh JK, Kim SH, Oh S, Kang DK. Isolation and characterization of an anti-listerial bacteriocin from Leuconostoc lactis SD501. Korean J Food Sci Anim Resour. 2018;38(5):1008-18.

13. Dan T, Liu W, Sun Z, Lv Q, Xu H, Song Y, Zhang H. A novel multi-locus sequence typing (MLST) protocol for Leuconostoc lactis isolates from traditional dairy products in China and Mongolia. BMC Microbiol. 2014:14:150.

14. de Moraes GMD, de Abreu LR, do Egito AS, Salles HO, da LMF S, Nero LA, Todorov SD, KMO DS. Functional properties of Lactobacillus mucosae strains isolated from brazilian goat milk. Probiotics Antimicrob. Proteins. 2017;9(3): 235-45.

15. Azad MAK, Sarker M, Li T, Yin J. Probiotic species in the modulation of gut microbiota: an overview. Biomed Res Int. 2018;2018:9478630.

16. Bubnov RV, Babenko LP, Lazarenko LM, Mokrozub W, Demchenko OA Nechypurenko OV, Spivak MY. Comparative study of probiotic effects of Lactobacillus and Bifidobacteria strains on cholesterol levels, liver morphology and the gut microbiota in obese mice. EPMA J. 2017;8(4):357-76.

17. Ogunremi OR, Sanni Al, Agrawal R. Probiotic potentials of yeasts isolated from some cereal-based Nigerian traditional fermented food products. J Appl Microbiol. 2015;119(3):797-808.

18. Piwat S, Sophatha B, Teanpaisan R. An assessment of adhesion, aggregation and surface charges of Lactobacillus strains derived from the human oral cavity. Lett Appl Microbiol. 2015;61(1):98-105.

19. Coman MM, Verdenelli MC, Cecchini C, Bela B, Gramenzi A, Orpianesi C, Cresci A, Silvi S. Probiotic characterization of Lactobacillus isolates from canine faeces. J Appl Microbiol. 2019;126(4):1245-56.

20. Tafti AG, Peighambardoust SH, Hesari J, Bahrami A, Bonab ES. Physicochemical and functional properties of spray-dried sourdough in breadmaking. Food Sci Technol Int. 2013;19(3):271-8.

21. Simpson PJ, Stanton C, Fitzgerald GF, Ross RP. Intrinsic tolerance of Bifidobacterium species to heat and oxygen and survival following spray drying and storage. J Appl Microbiol. 2005;99(3):493-501.

22. Martins E, Cnossen DC, Silva CRJ, Cezarino JCJ, Nero LA, Perrone IT, Carvalho AF. Determination of ideal water activity and powder temperature after spray drying to reduce Lactococcus lactis cell viability loss. J Dairy Sci. 2019; 102(7):6013-22.
23. De Angelis $M$, Siragusa $S$, Berloco $M$, Caputo $L$, Settanni $L$, Alfonsi G, Amerio M, Grandi A, Ragni A, Gobbetti M. Selection of potential probiotic lactobacilli from pig feces to be used as additives in pelleted feeding. Res Microbiol. 2006;157(8):792-801.

24. Rastogi S, Mittal V, Singh A. In vitro evaluation of probiotic potential and safety assessment of Lactobacillus mucosae strains isolated from donkey's lactation. Probiotics Antimicrob Proteins. 2019.

25. Gao W, Sun W, Yin J, Lv X, Bao J, Yu J, Wang L, Jin C, Hu L. Screening candidate microRNAs (miRNAs) in different lambskin hair follicles in $\mathrm{Hu}$ sheep. PLoS One. 2017;12(5):e0176532.

26. Balthazar CF, Silva HLA, Esmerino EA, Rocha RS, Moraes J, Carmo MAV, Azevedo L, Camps I, Abud YKD, Sant'Anna C, et al. The addition of inulin and Lactobacillus casei 01 in sheep milk ice cream. Food Chem. 2018;246: 464-72.

27. Pisano MB, Deplano M, Fadda ME, Cosentino S. Microbiota of sardinian goat's milk and preliminary characterization of prevalent $L A B$ species for starter or adjunct cultures development. Biomed Res Int. 2019;2019:6131404.

28. EE H, Ma L, Xie X, Ma J, Ma X, Yue C, Ma Q, Liang X, Ding W, Li Y. Genetic polymorphism association analysis of SNPs on the species conservation genes of Tan sheep and Hu sheep. Trop Anim Health Prod. 2020;52(3):915-26.

29. Wang $Q$, Wang $Y$, Hussain T, Dai C, Li J, Huang P, Li Y, Ding X, Huang J, Ji F, et al. Effects of dietary energy level on growth performance, blood parameters and meat quality in fattening male Hu lambs. J Anim Physiol Anim Nutr. 2020;104(2):418-30.

30. Somashekaraiah R, Shruthi B, Deepthi BV, Sreenivasa MY. Probiotic properties of lactic acid bacteria isolated from neera: a naturally fermenting coconut palm nectar. Front Microbiol. 2019;10:1382.

31. Chaikaew S, Baipong S, Sone T, Kanpiengjai A, Chui-Chai N, Asano K, Khanongnuch C. Diversity of lactic acid bacteria from Miang, a traditional fermented tea leaf in northern Thailand and their tannin-tolerant ability in tea extract. J Microbiol. 2017;55(9):720-9.

32. Dowarah $R$, Verma AK, Agarwal N, Singh $P$, Singh BR. Selection and characterization of probiotic lactic acid bacteria and its impact on growth, nutrient digestibility, health and antioxidant status in weaned piglets. PLoS One. 2018;13(3):e0192978.

33. Vasiee A, Alizadeh Behbahani B, Tabatabaei Yazdi F, Mortazavi SA, Noorbakhsh $\mathrm{H}$. Diversity and probiotic potential of lactic acid bacteria isolated from horreh, a traditional iranian fermented food. Probiotics Antimicrob Proteins. 2018;10(2):258-68.

34. Chelliah R, Ramakrishnan SR, Prabhu PR, Antony U. Evaluation of antimicrobial activity and probiotic properties of wild-strain Pichia kudriavzevii isolated from frozen idli batter. Yeast. 2016:33(8):385-401.

35. Kouitcheu Mabeku LB, Eyoum Bille B, Tepap Zemnou C, Tali Nguefack LD, Leundji $\mathrm{H}$. Broad spectrum resistance in Helicobacter pylori isolated from gastric biopsies of patients with dyspepsia in Cameroon and effluxmediated multiresistance detection in MDR isolates. BMC Infect Dis. 2019; 19(1):880.

36. Kaur $M$, Singh $H$, Jangra $M$, Kaur L, Jaswal $P$, Dureja $C$, Nandanwar $H$, Chaudhuri SR, Raje M, Mishra S, et al. Lactic acid bacteria isolated from yak milk show probiotic potential. Appl Microbiol Biotechnol. 2017;101(20):7635-52.

37. Colombo M, Castilho NPA, Todorov SD, Nero LA. Beneficial properties of lactic acid bacteria naturally present in dairy production. BMC Microbiol. 2018;18(1):219.

38. Gebreyohannes G, Moges F, Sahile S, Raja N. Isolation and characterization of potential antibiotic producing actinomycetes from water and sediments of Lake Tana, Ethiopia. Asian Pac J Trop Bimed. 2013;3(6):426-35.

39. Vesterlund S, Karp M, Salminen S, Ouwehand AC. Staphylococcus aureus adheres to human intestinal mucus but can be displaced by certain lactic acid bacteria. Microbiology. 2006;152(Pt 6):1819-26.

40. Dlamini ZC, Langa RLS, Aiyegoro OA, Okoh Al. Safety evaluation and colonisation abilities of four lactic acid bacteria as future probiotics. Probiotics Antimicrob Proteins. 2019;11(2):397-402

41. Monika S, Kumar V, Kumari A, Angmo K, Bhalla TC. Isolation and characterization of lactic acid bacteria from traditional pickles of Himachal Pradesh, India. J Food Sci Technol. 2017;54(7):1945-52.

42. Noda M, Danshiitsoodol N, Inoue Y, Okamoto T, Sultana N, Sugiyama M Antibiotic susceptibility of plant-derived lactic acid bacteria conferring health benefits to human. J Antibiot. 2019;72(11):834-42.

43. Kou X, Chen Q, Ju X, Liu H, Chen W, Xue Z. A tolerant lactic acid bacteria, Lactobacillus paracasei, and its immunoregulatory function. Can J Microbiol. 2014;60(11):729-36. 
44. Reuben RC, Roy PC, Sarkar SL, Alam RU, Jahid IK. Isolation, characterization, and assessment of lactic acid bacteria toward their selection as poultry probiotics. BMC Microbiol. 2019;19(1):253.

45. Shuhadha MF, Panagoda GJ, Madhujith T, Jayawardana NW. Evaluation of probiotic attributes of Lactobacillus sp. isolated from cow and buffalo curd samples collected from Kandy. Ceylon Med J. 2017;62(3):159-66.

46. Quigley L, O'Sullivan O, Stanton C, Beresford TP, Ross RP, Fitzgerald GF, Cotter PD. The complex microbiota of raw milk. FEMS Microbiol Rev. 2013; 37(5):664-98.

47. Wesolowska A, Sinkiewicz-Darol E, Barbarska O, Bernatowicz-Lojko U, Borszewska-Kornacka MK, van Goudoever JB. Innovative techniques of processing human milk to preserve key components. Nutrients. 2019;11(5): 1169.

48. Huang S, Chen XD. Significant effect of $\mathrm{Ca} 2+$ on improving the heat resistance of lactic acid bacteria. FEMS Microbiol Lett. 2013;344(1):31-8.

49. Zhang D, Ji H, Liu H, Wang S, Wang J, Wang Y. Changes in the diversity and composition of gut microbiota of weaned piglets after oral administration of Lactobacillus or an antibiotic. Appl Microbiol Biotechnol. 2016;100(23): 10081-93.

50. Ji K, Jang NY, Kim YT. Isolation of lactic acid bacteria showing antioxidative and probiotic activities from kimchi and infant feces. J Microbiol Biotechnol. 2015;25(9):1568-77.

51. Hou Q, Bai X, Li W, Gao X, Zhang F, Sun Z, Zhang H. Design of primers for evaluation of lactic acid bacteria populations in complex biological samples. Front Microbiol. 2018;9:2045.

52. Srivatstava A, Ginjupalli K, Perampalli NU, Bhat N, Ballal M. Evaluation of the properties of a tissue conditioner containing origanum oil as an antifungal additive. J Prosthet Dent. 2013;110(4):313-9.

53. Ren W, Liu G, Yin J, Chen S, Li T, Kong X, Peng Y, Yin Y, Hardwidge PR. Draft Genome Sequence of Enterotoxigenic Escherichia coli Strain W25K. Genome Announc. 2014;2(3):675.

54. Niederle MV, Bosch J, Ale CE, Nader-Macias ME, Aristimuno Ficoseco C, Toledo LF, Valenzuela-Sanchez A, Soto-Azat C, Pasteris SE. Skin-associated lactic acid bacteria from north American bullfrogs as potential control agents of Batrachochytrium dendrobatidis. PLoS One. 2019;14(9):e0223020.

55. Del Re B, Sgorbati B, Miglioli M, Palenzona D. Adhesion, autoaggregation and hydrophobicity of 13 strains of Bifidobacterium longum. Lett Appl Microbiol. 2000;31(6):438-42.

56. $\mathrm{Xu} \mathrm{H}$, Jeong HS, Lee HY, Ahn J. Assessment of cell surface properties and adhesion potential of selected probiotic strains. Lett Appl Microbiol. 2009; 49(4):434-42.

57. Zhang B, Wang Y, Tan Z, Li Z, Jiao Z, Huang Q. Screening of probiotic activities of lactobacilli strains iolated from traditional tibetan qula, a raw yak milk cheese. Asian Australas J Anim Sci. 2016;29(10):1490-9.

58. Azat R, Liu Y, Li W, Kayir A, Lin DB, Zhou WW, Zheng XD. Probiotic properties of lactic acid bacteria isolated from traditionally fermented Xinjiang cheese. J Zhejiang Univ Sci B. 2016;17(8):597-609.

59. Corcoran BM, Stanton C, Fitzgerald GF, Ross RP. Survival of probiotic lactobacilli in acidic environments is enhanced in the presence of metabolizable sugars. Appl Environ Microbiol. 2005;71(6):3060-7.

\section{Publisher's Note}

Springer Nature remains neutral with regard to jurisdictional claims in published maps and institutional affiliations.

\section{Ready to submit your research? Choose BMC and benefit from:}

- fast, convenient online submission

- thorough peer review by experienced researchers in your field

- rapid publication on acceptance

- support for research data, including large and complex data types

- gold Open Access which fosters wider collaboration and increased citations

- maximum visibility for your research: over $100 \mathrm{M}$ website views per year

At $\mathrm{BMC}$, research is always in progress.

Learn more biomedcentral.com/submissions 